\title{
Pengaruh Return on Asset, Net Profit Margin dan Current Ratio Terhadap Harga Saham Food and Beverage di Bursa Efek Indonesia
}

\author{
Januardin Manullang, Nanda Pratiwi, Refiensa Yohana Sihombing, Rifka Aulia Harahap, Kevin \\ Christian Tampubolon \\ Universitas Prima Indonesia, Medan ${ }^{1,2,3,4,5}$ \\ januardin.manullang@gmail.com, nandapratiwii98@gmail.com. \\ refiensasihombing@gmail.com, auliahrifka@gmail.com, \\ kevinchristiantampubolon@gmail.com
}

*Corresponding Author

Submitted: July 11, 2020

Accepted: September 27, 2020

Published: February 1, 2021

\begin{abstract}
This study aims to examine the effect of Return on Asset, Net Profit Margin and Current Ratio on Food and Beverage Stock Prices listed on the Indonesia Stock Exchange for the 2014-2018 period. The population in this study were all companies in the Food and Beverage sub-sector listed on the Indonesia Stock Exchange, amounting to 15 companies with a sample of 11 companies with the 2014-2018 period for 5 years and using a sampling technique, namely purposive sampling. The method of analysis used in this research is the Multiple Linear Regression Method. This research uses quantitative research. This type of research is descriptive statistics and the nature of the research is explanatory. The results of this study indicate that partially $(t)$ Return On Asset and Net Profit Margin have no and insignificant effect on Stock Prices, while Current Ratio has a negative effect on Food and Beverage Stock Prices which simultaneously affect Return On Asset, Net Profit Margin, and Current Ratio. to the Food and Beverage Stock Price
\end{abstract}

Keywords: Return On Asset, Net Profit Margin, Current Ratio and Stock Price

\section{PENDAHULUAN}

Bursa Efek Indonesia merupakan pasar modal untuk berbagai instrument keuangan jangka panjang yang dapat diperjual-belikan baik dalam bentuk utang ataupun modal sendiri. Di Indonesia perkembangan perusahaan manufaktur yang terdaftar di Bursa Efek Indonesia dari tahun ke tahun bertambah. Maka tidak menutup kemungkinan perusahaan sub sektor food and beverage sangat dibutuhkan oleh masyarakat dan prospeknya akan menguntungkan di masa kini maupun yang akan datang. Perusahaan sub sektor food and beverage merupakan salah satu industri yang juga memiliki peranan penting dalam kegiatan perekonomian negara Indonesia dan salah satu sektor industri yang cukup menarik. Produk barang konsumsi dari waktu ke waktu selalu dibutuhkan manusia karena barang konsumsi menjadi bahan pokok kehidupan manusia. Ini juga didukung dengan SDM yang jumlahnya cukup besar dan menyebabkan di Indonesia banyak perusahaan yang berkembang di sektor industri barang konsumsi.

Namun perusahaan sub sektor Food and Beverage ini juga mengalami fluktuasi dalam pertumbuhan laba sepanjang tahun 2014-2018, hal tersebut disebabkan oleh sejumlah permasalahan diantaranya karena kurangnya bahan baku, infrastruktur yang terbatas, kurangnya pasokan listrik dan gas dan suku bunga yang tinggi untuk investasi. Pertumbuhan industri makanan dan minuman di akhir juni 2017 melambat dibandingkan hasil triwulan I-2017. Hal ini dikatakan oleh Menteri Perindustrian, Airlangga Hartato saat membuka pameran Makanan dan Minuman di Plasa Pameran Industri, Gedung Kementrian Perindustrian. Dimana pertumbuhan industri Makanan dan Minuman pada triwulan kedua 2017 mengalami perlambatan pertumbuhan sebesar 7,19\% dibandingkan dengan triwulan 1- 2017 sebesar 8,15\% (Porter, 2015). 
Berdasarkan permasalahan di atas tentu saja akan mempengaruhi pertumbuhan laba pada emiten perusahaan Food and Beverage, diantaranya pada PT Wilmar Cahaya Tbk (CEKA) Tahun 2014 mengalami penurunan penjualan bersih sebesar 54,16\% menjadi Rp. 875,46 milyar, dari posisi penjualan bersih sebesar Rp. 1,91 triliun per maret 2014 (Setia, 2016). Selanjutnya pada PT.Multi Bintang Tbk (MLBI) membukukan laba bersih sebesar Rp.353,47 milyar per kuartal III2015 atau turun 29,39 \% dari posisi laba sebesar Rp.500,66 milyar per kuartal III-2014. dengan perolehan laba yang menurun yang disebabkan oleh penjualan perseroan yang melemah menjadi Rp. 1,7 triliun per september 2015, bila dibandingkan dengan penjualan tahun 2014 sebesar 2 triliun (Http://dankost.dk/referencer/, n.d.). Permasalahan tersebut tentu saja turut berdampak pada pertumbuhan Harga Saham dimana dapat dilihat pada perusahaan PT Prasida Aneka Niaga Tbk.

Pada tahun 2018 membukukan penurunan terdalam pada perdagangan per tanggal 12/11/2018. Berdasarkan data Bursa Efek Indonesia (BEI), Harga Saham bersandi PSDN ini memimpin pelemahan saham (top losers) setelah ditutup melemah $15,24 \%$ dan ditutup dilevel Rp 178 per lembar saham. (Pinjaman et al., n.d.).

Berdasarkan fenomena diatas dapat dilihat perubahan harga saham mengalami penurunan selama periode 2014-2018. Faktor-faktor yang mempengaruhi naik turunnya harga saham antara lain, faktor internal merupakan faktor yang dilihat dari dalam perusahaan yang sifatnya spesifik atas saham tersebut seperti penjualan, kinerja keuangan, kinerja manajemen, kondisi perusahaan dan industri dimana perusahaan tersebut bergerak. Sedangkan faktor eksternal merupakan faktorfaktor yang sifatnya makro dalam mempengaruhi harga saham di Bursa seperti inflasi, tingkat suku bunga, nilai tukar mata uang asing dan faktor non ekonomi seperti kondisi sosial, politik dan dan faktor lainnya (Nordiana \& Budiyanto, 2013).

Perusahaan mempunyai berbagai macam usaha dalam menarik jumlah investor dan meningkatkan harga sahamnya, salah satunya dengan mengevaluasi faktor-faktor yang sangat berpengaruh terhadap peningkatan harga saham suatu perusahaan. (Moorcy, 2018) Salah satu faktor yang mempengaruhi besarnya permintaan saham dan penawaran saham adalah tingkat hara saham. Harga saham mencerminkan nilai dari suatu perusahaan karena jika perusahaan mencapai prestasi yang baik maka saham perusahaan tersebut akan banyak diminati oleh para investor (Junaeni, 2017).

\section{Pengertian ROA}

\section{STUDI LITERATUR}

Hery (2015:193), menjelaskan Return On Asset yaitu suatu kegiatan dalam menghasilkan pengembalian atas aset perusahaan yang merupakan nilai dari besar kontribusi aset dalam menciptakan laba bersih, atau jika disimpulkan bahwa, rasio ini digunakan untuk mengukur seberapa besar jumlah laba bersih yang akan dihasilkan dari setiap rupiah dana yang tertanam dalam total aset. Indikator Return On Asset Menurut (Hery, 2015:193) adalah :

$$
\text { Return On Asset }=\frac{\text { LABA BERSIH }}{\text { TOTAL ASSET }}
$$

\section{Pengertian Net Profit Margin (NPM)}

Hery (2015:198), mengukur besarnya persentase laba bersih atas penjualan bersih pada perusahan maka dapat dilakukan dengan membagi laba bersih terhadap penjualan bersih adalah pengertian dari NPM. Indikator NPM Menurut Hery (2015: 198 adalah :

$$
\text { Net Profit Margin }=\frac{\text { LABA BERSIH }}{\text { PENJUALAN BERSIH }}
$$

\section{Pengertian Current Ratio}

Menurut Hery (2015:134), rasio lancar merupakan rasio yang digunakan untuk mengukur kemampuan perusahaan dalam memenuhi kewajiban jangka pendeknya yang segera jatuh tempo dengan menggunakan total aset lancar yang tersedia. Indikator Current Ratio untuk mencari rasio lancar (Current Ratio) menurut Hery (2015:135) dapat digunakan sebagai berikut: 


$$
\text { Current Ratio }=\frac{\text { ASET LANCAR }}{\text { KEWAJIBAN LANCAR }}
$$

\section{Pengertian Harga Saham}

(Kasmir,2018:205), harga saham merupakan bukti surat tanda kepemilikan suatu perusahaan atas nama saham yang dibelinya. Saham dapat diperjual belikan kepada pihak lain. Indikator Harga Saham (Tandelilin,2010:136), melihat rasio-rasio keuangan perusahaan adalah dasar pertimbangan para pemegang saham melakukan penawaran dan permintaan.

\section{Harga Saham = closing price}

\section{Pengaruh Return On Asset Terhadap Harga Saham}

Harmono (2018:110), profitabilitas memiliki Pengaruh terhadap nilai perusahaan. Sedangkan nilai perusahaan secara konsep dapat dijelaskan oleh nilai yang ditentukan oleh harga saham yang diperjual belikan di pasar modal.

Penelitian terdahulu penelitian yang pernah dilakukan oleh (Meyer et al., 1970) dengan judul pengaruh Return On Asset, Return On Equity, Net Profit Margin dan Earning Per Share terhadap Harga Saham. Peneliti mendapatkan Return On Asset tidak memiliki pengaruh terhadap harga Saham.

$\mathrm{H}_{1} \quad$ :Return On Asset berpengaruh terhadap Harga Saham

\section{Pengaruh Net Profit Margin Terhadap Harga Saham}

(Harahap,2015:304), Profit margin menunjukkan seberapa besar presentase pendapatan bersih yang diperoleh dari setiap penjualan. Apabila rasio ini semakin besar maka semakin baik karena dianggap kemampuan perusahaan dalam mendapatkan laba cukup tinggi. Hal tersebut dapat mempengaruhi minat para investor untuk menanamkan modal sehingga hal tersebut berdampak pada kenaikan harga saham.

Penelitian terdahulu penelitian yang pernah dilakukan oleh (Hutapea et al., 2017) dengan judul Pengaruh Return On Asset, Net Profit Margin, Dept to Equity Ratio, Dan Total Asset Turn Over pada Harga Saham.. Peneliti mendapatkan Net Profit Margin tidak berpengaruh signifikan kepada Harga saham.

$\mathrm{H}_{2} \quad$ :Net Profit Margin Berpengaruh Terhadap Harga Saham

\section{Teori Pengaruh Current Ratio Terhadap Harga Saham}

Menurut (Fahmi,2016:62), perusahaan yang mempunyai rasio likuiditas tinggi akan disukai para investor dan akan berimbas pula pada harga saham yang cenderung akan naik karena tingginya permintaan. Telah menjadi sifat seorang investor untuk tetap menyukai saham dengan resiko yang kecil dan selalu mengalami peningkatan harga.

Penelitian terdahulu Hasil penelitian ini didukung oleh penelitian terdahulu yang di teliti oleh (Gunawan et al., 2020) dengan judul pengaruh Current Ratio, Debt To Equity Ratio, Earning Per Share dan Financial Distress terhadap Harga Saham. yang menyatakan bahwa secara parsial $C R$ berpengaruh negatif terhadap Harga Saham.

$\mathrm{H}_{3} \quad$ :Current Ratio Berpengaruh Terhadap Harga Saham

\section{METODE}

Penelitian ini menggunakan pendekatan kuantitatif. Sugiyono (2017:08) menjelaskan bahwa, penelitian kuantitatif merupakan metode penelitian yang berlandaskan pada filsafat positivisme, digunakan untuk meneliti pada populasi atau sampel tertentu. Metode penelitian yang digunakan adalah metode deskrtiptif. Menurut (Sujarweni, 2014 :11) metode deskriptif adalah penelitian yang dilakukan untuk mengetahui nilai masing-masing variabel, baik satu variabel atau lebih sifatnya independen tanpa membuat hubungan maupun perbandingan dengan variabel yang lain. Jenis data yang digunakan adalah data sekunder. data sekunder adalah data yang sudah tersedia dan dikumpulkan oleh pihak lain (Sanusi, 2014: 104) data sekunder dalam penelitian ini yaitu data yang diperoleh secara tidak langsung yang di publikasikan oleh Bursa Efek Indonesia 
melalui situs https://www.idnfinancial.com, laporan keuangan subsektor Food and Beverage di Bursa Efek Indonesia Pada Periode 2014-2018, jurnal, surat kabar serta buku-buku referensi yang berkaitan dengan judul penelitian.

\section{Populasi dan Sampel}

Populasi pada penelitian ini Subsektor Industri Food and Beverage yang terdaftar di BEI periode 2014-2018 sebanyak 15 Perusahaan. Teknik penarikan sampel dengan menggunakan purposive sampling yang merupakan satu teknik dalam pengambilan sampel dengan beberapa pertimbangan tertentu (Sugiyono,2017:124).

Tabel 1. Kriteria Pengambilan Sampel Penelitian

\begin{tabular}{|c|l|c|}
\hline No. & \multicolumn{1}{|c|}{ Kriteria } & $\begin{array}{c}\text { Jumlah } \\
\text { Sampel }\end{array}$ \\
\hline 1 & $\begin{array}{l}\text { Perusahaan Sub Sektor Industri Food and Beverage yang terdaftar } \\
\text { di Bursa Efek Indonesia Periode 2014-2018. }\end{array}$ & 15 \\
\hline 2 & $\begin{array}{l}\text { Perusahaan Sub Sektor Industri Food and Beverage yang } \\
\text { mempublikasikan laporan keuangan secara berturut selama Periode } \\
\text { 2014-2018. }\end{array}$ & 15 \\
\hline 3 & $\begin{array}{l}\text { Perusahaan Sub Sektor Industri Food and Beverage yang memiliki } \\
\text { laba selama periode 2014-2018. }\end{array}$ & 11 \\
\hline Jumlah Perusahaan Yang Menjadi Sampel Penelitian & 11 \\
\hline \multicolumn{2}{|l|}{ Data Observasi Penelitian 11 5 5 } \\
\hline
\end{tabular}

\section{Statistik Deskriptif}

\section{HASIL}

Sampel pada penelitian ini sebanyak 11 perusahaan dengan periode penelitian dari 20142018 sehingga diperoleh data sejumlah 55 data penelitian. Hasil pengolahan data dapat dilihat pada tabel deskiriptif statistik dibawah ini:

Tabel. 2 Statistik deskriptif

\begin{tabular}{|l|c|c|c|c|c|}
\hline & N & Minimum & Maximum & Mean & Std. Deviation \\
\hline LN_ROA & 55 & -4.71 & -.64 & -2.3289 & .78493 \\
LN_NPM & 55 & -4.80 & -.94 & -2.5186 & .92230 \\
LN_CR & 55 & -.67 & 2.16 & .6958 & .62466 \\
LN_HS & 55 & .00 & 6.85 & 2.1360 & 2.05057 \\
Valid N & 55 & & & & \\
(listwise) & & & & & \\
& & & & & \\
\hline
\end{tabular}

Sumber : Data laporan keuangan diolah

\section{Uji Asumsi Klasik}

\section{Uji Normalitas}

(Ghozali, 2013:154) uji normalitas bertujuan untuk menguji apakah dalam model regresi, variabel pengganggu atau residual memiliki distribusi normal. Penelitian ini menggunakan uji histogram, scatterplot dan kolmogrov smirnov. Kriteria pengambilan keputusan adalah:

a. Jika nilai signifikansi lebih besar dari 5\% atau 0,05 maka Ho diterima, artinya data berdistribusi normal

b. Jika nilai signifikansi lebih kecil dari 5\% atau 0,05 maka Ha ditolak, artinya tidak berdistribusi normal

Hasil dari pengujian normalitas sebagai berikut: 


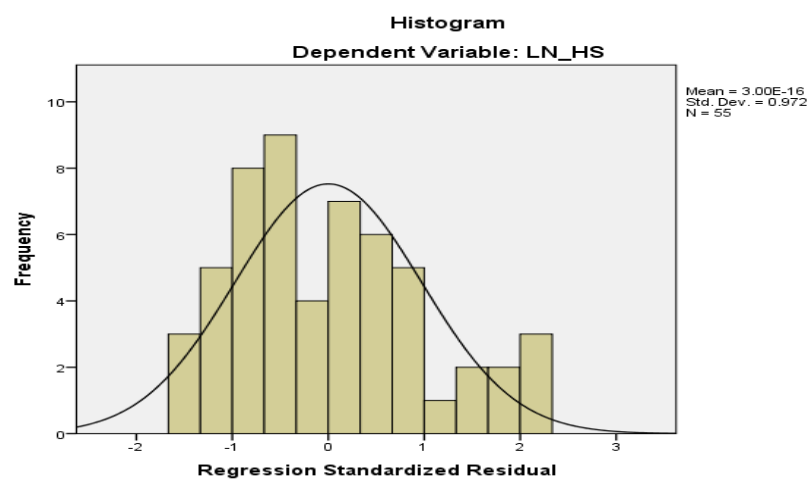

Gambar 1. Grafik Histogram

Hasil dari grafik diatas menunjukkan kurva berbentuk lonceng, sehingga hasil normalitas pada grafik histogram tersebut menunjukkan berdistribusi normal.

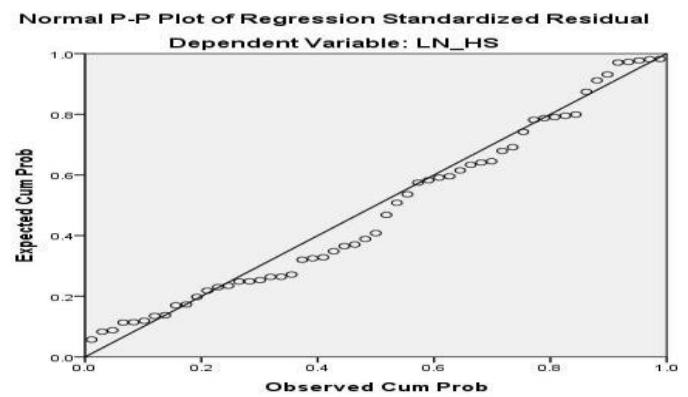

Gambar 2. Grafik P-P Plot

Grafik P-P plot pada gambar diatas terlihat, titik-titik menyebar didekat garis diagonal sehingga dapat disimpulakan data telah berdistribusi normal.

Tabel 3. Uji Normalitas (Kolmogrov - Smirnov)

\begin{tabular}{|l|c|c|}
\hline & & Unstandardized Residual \\
\hline $\mathrm{N}$ & & 55 \\
Normal Parameters $\square \square$ & Mean & $0 \mathrm{E}-7$ \\
& & \\
& Std.Deviation & 1.83788604 \\
& Absolute & .106 \\
Most Extreme Differences & Positive & .106 \\
& Negative & -.065 \\
\hline Kolmogorov-smirnov Z & & .784 \\
Asymp, Sig. (2-tailed) & & .571 \\
\hline
\end{tabular}

a.Tes $\mathrm{t}$ distributio $\mathrm{n}$ is Norma 1 .

b. Cal culated from data.

Hasil pengujian kolmogrov-smirnov diatas dapat dilihat bahwa nilai signifikan memenuhi syarat distribusi normal karena nilai signifikan lebih besar dari $0,05(0,571>0,05)$ sehingga model regresi ini bisa dipakai untuk dianalisis.

\section{Uji Multikolinearitas}

Ghozali (2013 : 103) Uji multikolinearitas untuk menguji apakah model regresi ditemukan adanya korelasi antar variabel bebas. Dalam penelitian ini untuk mendeteksi ada atau tidaknya multikolinearitas dengan menganalisis matrik korelasi antar variabel independen dan perhitungan 
nilai tolerance dan factor $(F I V)$, apabila tolerance value $>0,1$ atau VIF $<10$, maka tidak terjadi multikolinearitas, hasil multikolinearitas pada penelitian ini dapat dilihat pada tabel dibawah ini:

Tabel 4. Uji Multikolinearitas

Coefficients $^{\mathrm{a}}$

\begin{tabular}{|cc|c|c|}
\hline \multirow{2}{*}{ Model } & \multicolumn{2}{c|}{ Colliniearity Statistics } \\
\cline { 3 - 4 } & & Tolerance & VIF \\
\hline \multirow{4}{*}{1} & (Constant) & & \\
& LN_ROA & .357 & 2.799 \\
& LN_NPM & .344 & 2.908 \\
& LN_CR & .933 & 1.071 \\
\hline
\end{tabular}

a.Dependent Variable: LN_HS

Berdasarkan tabel .3 menunjukkan bahwa tidak terjadi gejala multikolinearitas antar variabel penelitian. Hal ini ditunjukkan dalam angka VIF (variance inflation factor) dari Return On Asset, Net Profit Margin dan Current Ratio lebih kecil dari 10 dan nilai tolerance dari Return On Asset, Net Profit Margin dan Current Ratio yang lebih besar dari 0,10.

\section{Uji Autokorelasi}

Ghozali (2013:107) menjelaskan bahwa autokorelasi bertujuan untuk menguji apakah dalam regresi linear ada korelasi antara kesalah pengganggu pada periode $t$ dengan kesalahan penganggu pada periode t-1 (sebelumnya). Cara yang digunakan untuk melihat ada atau tidaknya autokorelasi pada penelitian ini adalah dengan uji runs test yang merupakan bagian dari statistik non-parametik yang dapat digunakan untuk menguji apakah antar residual terdapat korelasi yang tinggi, dimana kriteria pengambilan keputusannya adalah Jika nilai Asym.Sig (2-taield) kurang dari 0,05 maka data residual terjadi secara tidak random (sistematis) dan jika nilai Asympo.sig. ( 2taield) lebih besar dari 0,05 maka data residual terjadi secara random (acak) (Ghozali , 2013:116) hasi runs test dapat dilihat pada tabel dibawah ini:

\begin{tabular}{|c|c|}
\hline \multicolumn{2}{|c|}{ Tabel 5. Uji Autokorelasi (Runs Test) } \\
\hline & Unstandardized Residual \\
\hline Test Value $\square$ & -.43924 \\
\hline Cases $<$ Test Value & 27 \\
\hline Cases $>=$ Test Value & 28 \\
\hline Total Cases & 55 \\
\hline Number of Runs & 32 \\
\hline $\mathrm{Z}$ & .956 \\
\hline Asymp. Sig. (2-tailed) & .339 \\
\hline
\end{tabular}

a. Median

Berdasarkan tabel 5 diatas, dapat dilihat bahwa nilai Asymp. Sig. (2-taield) $0.339>0,05$ sehingg dapat disimpulkan bahwa residual terjadi secara random (acak) atau tidak adanya gejala autokorelasi.

\section{Uji Heteroskedastitas}

Ghozali (2013: 137) menjelaskan bahwa, uji heteroskedastisitas digunakan untuk menguji apakah dalam model regresi terjadi ketidaksamaan variance dari residual satu pengamatan ke pengamatan yang lain. Metode dalam menetukan uji heteroskedastisitas pada penelitian ini adalah dengan menggunakan uji glegser, uji glegser dilakukan dengan cara meregresikan antara variabel independen absolut residualnya. Jika nilai signifikan antara variabel independen dengan absolut residual lebih dari 0.05 maka tidak terjadi masalah heteroskedastisitas. Hasil pengujian heteroskedastisitas pada penelitian ini dapat dilihat pada tabel dibawah ini: 
Tabel 6. Hasil Pengujian Heteroskedastisitas (Uji Glejser)

\begin{tabular}{|c|c|c|c|c|c|}
\hline \multirow{2}{*}{ Model } & \multicolumn{2}{|c|}{ Unstandardized Coefficients } & Standardized Coefficients & t & sig \\
\cline { 2 - 6 } & B & Std. Error & Beta & & \\
\hline (Constant ) & .147 & .441 & & .333 & .741 \\
LN_ROA & -.386 & .266 & -.296 & -1.449 & .154 \\
1 LN_NPM & -.225 & .231 & -.202 & -.972 & .335 \\
LN_CR & -.141 & 207 & -.086 & -.682 & .498 \\
\hline
\end{tabular}

a.Dependent variable : RES2

Tabel 6 diketahui nilai signifIkan variabel ROA sebesar 0, $154>0,05$, NPM sebesar $0,335>0,05$ dan $\mathrm{CR}$ sebesar 0,498>0,05 sehingga diambil kesimpulan bahwa tiak terjadi heteroskedastisitas.

\section{Hasil Analisis Data Penelitian}

Penelitian ini menggunakan pengujian hipotesis analisis regresi linier berganda dengan hasil persamaan regresi sebagai berikut:

Tabel 7. Persamaan Regresi

Coefficients $^{\mathrm{a}}$

\begin{tabular}{|l|c|c|c|}
\hline \multirow{2}{*}{ Model } & \multicolumn{2}{|c|}{ Unstandardized Coefficients } & Standardized Coefficients \\
\cline { 2 - 4 } & B & Std.Error & Beta \\
\hline (Constant) & .937 & .909 & -.255 \\
LN_ROA & -.666 & .549 & -.058 \\
1 LN_NPM & -.129 & .476 & -.296 \\
\hline LN_CR & -.972 & .426 & \\
\hline
\end{tabular}

a. Dependent variable : LN_HS

Berdasarkan tabel diatas diperoleh rumus regresi sebagai berikut:

LN_Harga Saham = 0,937 - 0,666 (LN_Return On Asset) - 0, 129 (LN_Net Profit Margin) -0,972 (LN_Current Ratio).

Adapun makna persamaan regresi linier berganda diatas adalah :

1. Konstanta (a) $=0,937$ menunjukkan bahwa apabila tidak ada nilai variabel independent yaitu LN_Return On Asset, Net Profit Margin dan Current Ratio, maka nilai LN_Harga Saham yang dilihat dari nilai Y akan meningkat sebesar 0,937 satuan.

2. Koefisien regresi LN_Return On Asset $=-0,666$ menunjukkan bahwa setiap kenaikan LN_Return On Asset sebesar 1 satuan, maka LN_Harga Saham yang terlihat dari nilai Y akan menurun sebesar 0,666 satuan dengan asumsi variabel lain dianggap konstan.

3. Koefisien regresi LN_Net Profit Margin = - 0,129 menunjukkan bahwa setiap kenaikan LN_NPM sebesar 1 satuan, maka LN_Harga Saham yang terlihat dari nilai Y akan menurun sebesar -0,129 satuan dengan asumsi variabel lain dianggap konstan.

4. Koefisien regresi LN_Current Ratio $=-0,972$ menunjukkan bahwa setiap kenaikan LN_Current Ratio sebesar 1 satuan, maka LN_Harga Saham yang terlihat dari nilai Y akan menurun sebesar $-0,972$ satuan dengan asumsi variabel lain dianggap konstan.

\section{Koefisien determinasi hipotesis}

Ghozali (2013:95) menjelaskan bahwa uji ini dilakukan untuk mengetahui sebesar apakah kemampuan model dalam menerangkan variabel terikat. Kritria nya adalah apabila nilai $\mathrm{R}^{2}$ dengan mendekati angka 0 maka variabel bebas tidak menjelaskan variabel terikat, sebaliknya jika 
$\mathrm{R}^{2}$ mencapai angka 1 artinya variabel bebas dapat memberikan penjelasan untuk memprediksi variabel terikat.

Tabel 8. Koefisien Determinasi Hipotesis

Model Summary ${ }^{\mathrm{b}}$

\begin{tabular}{|c|c|c|c|c|}
\hline Model & R & R Square & Adjusted R Square & Std. Error of the Estimate \\
\hline 1 & .443 & .197 & .149 & 1.8911691 \\
\hline
\end{tabular}

a. Predictors: (Constant), LN_CR, LN_ROA, LN_NPM

b. Dependent Variable: LN_HARGASAHAM

Berdasarkan tabel diatas dapat dilihat nilai Adjusted $R$ Square sebesar 0,149, bararti 14,9 $\%$ variasi harga saham bisa dijelaskan oleh variasi dari ketiga variabel independent Return On Asset, Net Profit Margin dan Current Ratio. $(100 \%$ - 14,9\% = 85,1\%) dijelaskan oleh sebab-sebab yang lain diluar model.

\section{Pengujian hipotesis secara simultan (F)}

Ghozali (2013:96) Uji bertujuan untuk menguji apakah semua variabel independen mempengaruhi variabel dependen secara bersama-sama. Hasil pengujian simultan pada penelitian ini dapat dilihat pada tabel dibawah ini.

Tabel 9. Uji F

ANOVA

\begin{tabular}{|cl|c|c|c|c|c|}
\hline & & Sum of Square & df & mean square & F & Sig. \\
\hline \multirow{4}{*}{1} & Regression & 44.659 & 3 & 14886 & 4162 & $010^{\mathbf{b}}$ \\
& Residual & 182.403 & 51 & 3577 & & \\
& Total & 227.061 & 54 & & & \\
& & & & & & \\
\hline
\end{tabular}

a. Dependentt Varia ble: LN_HS

b. Predi ctors: (C onstant), LN_CR, LN_RO A, LN_NPM

Berdasarkan tabel diatas dapat dilihat hasil uji statistik F menghasilkan Fhitung sebesar 4,162 dengan nilai signifikan sebesar 0,010 dengan perhitungan df 1 (jumlah variabel-1) $=3$ dan df 2 $(\mathrm{n}-\mathrm{k}-1)=(55-3-1)=51$, maka diperoleh nilai $\mathrm{F}$ tabel adalah 2,79 dengan nilai signifikansi dibawah 0,05 yaitu sebesar 0.010. hasil dari statistik menunjukkan bahwa milai Fhitung sebesar 4,162 lebih besar dari Ftabel, $(4,162>2,79)$ dengan tingkat signifikan 0,05. Ini menunjukkan bahwa ROA, NPM dan CR berpengaruh secara bersama-sama terhadap Harga Saham pada subsektor Food and Beverage yang terdaftar di Bursa Efek Indonesia periode 2014-2018.

\section{Pengujian Hipotesis Secara Parsial (Uji t)}

Ghozali (2013:97) Uji statistik t pada dasarnya menunjukkan seberapa jauh pengaruh satu variabel penjelas/independen secara individual dalam menerangkan variabel-variabel dependen. Pengujian ini dilakukan untuk mengetahui seberapa jauh pengaruh variabel independen secara parsial (individual) menerangkan variasi variabel dependen. Hasil uji t dapat dilihat pada tabel dibawah ini.

Tabel 10. Uji

Coefficients $^{\mathrm{a}}$

\begin{tabular}{|c|l|l|l|l|l|}
\hline \multirow{2}{*}{ Model } & \multicolumn{2}{|c|}{$\begin{array}{c}\text { Unstandardized } \\
\text { Coefficients }\end{array}$} & $\begin{array}{c}\text { Standardized } \\
\text { Coefficients }\end{array}$ & t sig. \\
\cline { 2 - 4 } & B & Std.Error & Beta & & \\
\hline
\end{tabular}




\begin{tabular}{l|c|c|c|c|c|} 
(Constant) & .937 & .909 & & 1.031 & .307 \\
LN_ROA & -.666 & .549 & -.255 & -1.214 & .230 \\
1 & & & & & \\
LN_NPM & -.129 & .476 & -.058 & -.270 & .788 \\
LN_CR & -.972 & .426 & -.296 & -2.279 & .027 \\
\hline
\end{tabular}

a.Dependent Variable : LN_HS

Nilai ttabel sebesar 2,00856 Yang dapat diketahui dari rumus 0.05, $\mathrm{df}=\mathrm{n}-\mathrm{k}=55-3=52$.

Hasil pengujian statistik secara parsial sebagai berikut:

1. Variabel ROA (X1) memiliki nilai signifiikan $0,230>0.05$ da $n$ hasil thitung < ttabel $(-1,214$ $<2,00665$ ) maka H0 diterima dan Ha ditolak yang berarti bahwa variabel Return On Asset tidak berpengaruh dan tidak signifikan terhadap harga saham pada perusahaan sub sektor Food And Beverage yang terdaftar di Bursa Efek Indonesia pada periode 2014-2018.

2. Variabel NPM (X2) memiliki nilai signifikan 0,788 > 0.05 dan hasil thitung < ttabel $(-0,270<$ $2,00665)$ maka H0 diterima dan Ha ditolak yang berarti bahwa variabel Net Profit Margin tidak berpengaruh dan tidak signifikan terhadap harga saham pada perusahaan sub sektor Food And Beverage yang terdaftar di Bursa Efek Indonesia pada periode 2014-2018.

3. Variabel CR (X3) memiliki nilai signifikan 0,027 < 0.05 dan hasil thitung < ttabel $(-2,279<$ 2,00665) maka H0 ditolak dan Ha diterima yang berarti bahwa variabel Current Ratio berpengaruh negatif dan signifikan terhadap harga saham pada perusahaan sub sektor Food And Beverage yang terdaftar di Bursa Efek Indonesia pada periode 2014-2018.

\section{PEMBAHASAN}

Pengaruh Return On Asset Terhadap Harga Saham

Hasil pengujian secara parsial (uji statistik t) dapat dilihat bahwa nilai thitung sebesar $1,214<$ ttabel sebesar 2,00665 dan nilai signifikansi sebesar 0,230>0,05. Hasil ini menunjukkan kalau H0 diterima dan Ha ditolak artinya secara parsial Return On Asset tidak berpengaruh dan tidak signifikan terhadap harga saham pada sub sektor Food And Beverage yang terdaftar di Bursa Efek Indonesia pada periode 2014-2018.

Hasil penelitian ini berbeda dari teori menurut Harmono (2018:110), profitabilitas memiliki Pengaruh terhadap nilai perusahaan. Sedangkan nilai perusahaan secara konsep dapat dijelaskan oleh nilai yang ditentukan oleh harga saham yang diperjual belikan di pasar modal.

Hasil penelitian ini didukung oleh penelitian terdahulu yang di teliti oleh Gerald Edsel Y.E,. dkk (2017) yang menyatakan bahwa secara parsial Return On Asset tidak berpengaruh dan tidak signifikan terhadap Harga Saham.

\section{Pengaruh Net Profit Margin Terhadap Harga Saham}

Hasil pengujian secara parsial (uji statistik t) dapat dilihat bahwa nilai thitung sebesar $0,270<$ ttabel sebesar 2,00665 dan nilai signifikansi sebesar 0,788>0,05. Hasil penelitian ini menunjukkan kalau H0 diterima dan Ha ditolak artinya secara parsial NPM tidak berpengaruh dan tidak signifikan terhadap harga saham pada sub sektor Food And Beverage yang terdaftar di Bursa Efek Indonesia pada periode 2014-2018.

Hasil penelitian ini berbeda dengan teori Harahap (2015:304), Profit margin menunjukkan seberapa besar presentase pendapatan bersih yang diperoleh dari setiap penjualan. Apabila rasio ini semakin besar maka semakin baik karena dianggap kemampuan perusahaan dalam mendapatkan laba cukup tinggi. Hal tersebut dapat mempengaruhi minat para investor untuk menanamkan modal sehingga hal tersebut berdampak pada kenaikan harga saham.

Hasil penelitian ini didukung oleh penelitian terdahulu yang di teliti oleh Albertha W Hutapea, Dkk (2017) yang menyatakan bahwa secara parsial Net Profit Margin tidak berpengaruh dan tidak signifikan terhadap Harga Saham. 


\section{KESIMPULAN}

Pengujian secara parsial (uji T) untuk Return On Asset dan Net Profit Margin tidak berpengaruh dan tidak signifikan terhadap Harga Saham. Pengujian secara parsial (uji T) untuk Current Ratio berpengaruh negatif dan signifikan terhadap Harga Saham. Dan dari hasil pengujian yang dilakukan secara simultan bahwa Return On Asset, Net Profit Margin dan Current Ratio berpengaruh dan signifikan terhadap Harga Saham pada Perusahaan food and beverage yang terdaftar di Bursa Efek Indonesia selama periode 2014-2018.

\section{REFERENSI}

Fahmi, I. (2016). Pengantar Manajemen Keuangan Perusahaan. Alfabeta.

Ghozali, I. (2013). Aplikasi Analisis Multivariete Dengan Program IBM SPSS 21 (Edisi 8) (Edisi 8). Badan Penerbit Universitas Diponegoro.

Gunawan, J., Funny, F., Marcella, C., Evelyn, E., \& Sitorus, J. S. (2020). Pengaruh CR (Current Ratio), DER (Debt to Equity Ratio), EPS (Earning Per Share) dan Financial Distress (Altman Score) Terhadap Harga Saham Pada Perusahaan Sektor Industri Dasar dan Kimia Yang Terdaftar Di Bursa Efek Indonesia. Owner, 4(1), 1. https://doi.org/10.33395/owner.v4i1.176

Harahap, S. S. (2015). Analisis Kritis Laporan Keuangan. PT. Raja Grafindo Persada.

Harmono. (2018). Manajemen Keuangan. PT. Aksara.

Hery. (2015). Analisis Laporan Keuangan. Center For Academic Publishing.

Http://dankost.dk/referencer/. (n.d.). Link 3.

Hutapea, A. W., Saerang, I. S., \& Tulung, J. E. (2017). Pengaruh Return On Asset, Net Profit Margin, Debt to Equity Ratio dan Total Aset Turnover Terhadap Harga Saham Industri Otomotif Dan Komponen Yang Terdaftar di Bursa Efek Indonesia. Jurnal EMBA, 5(2), $541-552$.

Junaeni, I. (2017). Pengaruh Economic Value Added, Retrun On Asset, Debt to Equity Ratio dan Total Assets Turnover Terhadap Perusahaan Makanan dan Minuman yang Terdaftar di Bursa Efek Indonesia Tahun 2010-2014. Riset \& Jurnal Akuntansi, 2(1), 32-47.

Kasmir. (2018). Pengantar Manajemen Keuangan. Prenada Media Group.

Meyer, F. V., Corner, D. C., Parker, J. E. S., Meyer, F. V., Corner, D. C., \& Parker, J. E. S. (1970). Profitability. Problems of a Mature Economy, 5(1), 45-61. https://doi.org/10.1007/978-1-349-15400-5_6

Moorcy, N. hernadi. (2018). Faktor-Faktor Yang Mempengaruhi Harga Saham Perusahaan Food \& Beverages Yang Terdaftar Di Bursa Efek Indonesia. Jurnal GeoEkonomi, 9(1), 18-31. https://doi.org/10.36277/geoekonomi.v9i1.17

Nordiana \& Budiyanto. (2013). Summary for Policymakers. In Intergovernmental Panel on Climate Change (Ed.), Climate Change 2013 - The Physical Science Basis (Vol. 53, Issue 9, pp. 1-30). Cambridge University Press. https://doi.org/10.1017/CBO9781107415324.004

Pinjaman, F., Untuk, P., \& Tradisional, P. (n.d.). Link : 4 (Vol. 000, pp. 5-6).

Porter, S. (2015). Link 1 (pp. 11-13). https://books.google.com.co/books?id=6TkXrLIX3_8C\&pg=PA62\&dq=inversion+de+pie+ definicion $\& h l=e s \& s a=X \& v e d=0 a h U K E w j 4 o Y K u y P D d A h V G x 1 \mathrm{kKHVpKDJEQ6AEIKDA}$ $\mathrm{A} \# \mathrm{v}=$ onepage $\& \mathrm{q} \& \mathrm{f}=$ false

Sanusi, A. (2014). METODOLOGI PENELITIAN BISNIS (KE EMPAT). Salemba Empat.

Setia, M. S. (2016). Link 2. In Indian Dermatology (Vol. 61, Issue 3, pp. 261-264).

Sugiyono. (2017). Metode Penelitian Pendidikan. Alfabeta.

Sujarweni, V. W. (2014). . Metode Penelitian. Pustaka Baru Press.

Tandelilin, E. (2010). Analisis Investasi dan Manajemen Portofolio. BPFE, UGM. 